\title{
СОЦІАЛЬНО-ПРАВОВА ЗУМОВЛЕНІСТЬ КРИМІНАЛЬНОЇ ВІДПОВІДАЛЬНОСТІ ЗА УХИЛЕННЯ ВІД СПЛАТИ ПОДАТКІВ, ЗБОРІВ (ОБОВ'ЯЗКОВИХ ПЛАТЕЖІВ): ДОСТАТНІЙ СТУПІНЬ ПОШИРЕНОСТІ ЯК КРИТЕРІЙ КРИМІНАЛІЗАЦІЇ ДІЯННЯ
}

Гритенко О. А., Старинець $\epsilon$. А.

У статті висвітлюються та аналізуються доктринальні аспекти щодо встановлення соціальноправової зумовленості кримінальної відповідальності за ухилення від сплати податків, зборів (обов'язкових платежів) через з'ясування такого принципу (критерію) криміналізації діяння, як достатня ступінь поширеності. Окрему увагу приділено питанню соціально-правової зумовленості кримінально-правової норми, яка передбачає відповідальність за ухилення від сплати податків, зборів (обов'язкових платежів).

3'ясовано, що існують певні соціально-правові підстави (критерії) криміналізаціі зазначеного протиправного діяння, а саме: діяння повинно бути суспільно небезпечним; воно повинно мати достатню ступінь поширеності; очікувані позитивні наслідки криміналізації повинні перевищувати ії негативні наслідки; криміналізація не повинна суперечити Конституції України, чинному праву і міжнародним угодам України; вона не повинна суперечити нормам моральності; криміналізація повинна бути здійсненна в процесуальному і криміналістичному аспектах (тобто заборонене діяння буде мати можливість розкриття та розслідування законними правовими засобами); криміналізація не повинна проводитися, якщо боротьба з даними небезпечними для суспільства діяннями можлива й ефективна за допомогою інших, більш м'яких заходів. здійснено спробу оцінити соціально-правову зумовленість кримінально-правової заборони, встановленої у ст. 212 КК України, з позиції розгляду одного з перерахованих вище критеріїв криміналізації діянь (достатня ступінь поширеності).

Наведено статистичні дані офісу Генерального прокуратура України, дані ЄӘиного державного реєстру судових рішень, на підставі яких доведено соціально-правову зумовленість кримінальної відповідальності за ухилення від сплати податків, зборів (обов'язкових платежів) через установлення такого принципу (критерію) криміналізації діяння, як достатня ступінь поширеності.

Ключові слова: збори, криміналізація, критерії, кримінальне правопорушення, кримінальна відповідальність, зумовленість, обов'язкові платежі, принципи, підстави, податки, сплата, ухилення.
Hrytenko 0. A., Starynets Ye. A. Social legal dependence of criminal liability for failure to pay taxes and duties (compulsory payments): sufficient level of expansion as a factor to criminalize the act

The article highlights and analyzes the doctrinal aspects of establishing the social and legal conditionality of criminal liability for tax evasion, fees (mandatory payments) by clarifying such a principle (criterion) of criminalization of an act as a sufficient degree of prevalence. Special attention is paid to the issue of social and legal conditionality of the criminal law, providing for liability for evasion of taxes and fees (mandatory payments).

It has been found that certain social and legal grounds (criteria) for the criminalization of the specified illegal act, namely: the act, must be socially dangerous; it must be of sufficient prevalence; the expected positive consequences of criminalization must exceed its negative consequences; criminalization should not contradict the Constitution of Ukraine, current law and international agreements of Ukraine; it should not contradict moral norms; criminalization must be practicable in procedural and forensic aspects (that is, the prohibited act will be able to be disclosed and investigated by legal means); criminalization should not be carried out if the fight against these actions dangerous to society is possible and effective with the help of other, more lenient measures. An attempt has been made to assess the social and legal conditionality of the criminal law prohibition established in Art. 212 of the Criminal Code of Ukraine, from the perspective of considering one of the above criteria for the criminalization of acts (a sufficient degree of prevalence).

The author cites statistical data from the office of the Prosecutor General's Office of Ukraine, data from the Unified State Register of Court Decisions, on the basis of which he proves the social and legal conditionality of criminal liability for evading taxes, fees (mandatory payments) by establishing such a principle (criterion) of criminalization of an act as a sufficient degree of prevalence.

Key words: fees, criminalization, criteria, criminal offense, criminal liability, conditionality, obligatory payments, principles, grounds, taxes, payment, evasion.

() Гритенко О. А., Старинець Є. А., 2020 
Постановка проблеми та її актуальність. Проблема соціальної зумовленості кримінального закону $\epsilon$ багатоплановою. Центральне місце в ній займає проблема зумовленості вимог, які містяться в ньому, об'єктивних закономірностей суспільного розвитку [20, с. 3]. Окрему увагу привертає питання соціальної зумовленості кримінально-правової норми, яка передбачає відповідальність за ухилення від сплати податків, зборів (обов'язкових платежів). При цьому, враховуючи бланкетний вид диспозиції кримінально-правової норми, що передбачає відповідальність за ухилення від сплати податків, зборів (обов'язкових платежів), слід розглядати це питання у двох напрямах. Перший пов'язаний з інститутом оподаткування, другий із криміналізацією ухилення від сплати податків, зборів (інших обов'язкових платежів). Наша увага у цій статті зосереджена на криміналізації та їі загальних підставах (принципах, критеріях) по відношенню до ухилення від сплати податків, зборів (інших обов'язкових платежів).

Аналіз останніх досліджень i публікацій. Боротьба з ухиленням від сплати податків, зборів (обов'язкових платежів) $\epsilon$ пріоритетною для органів державної влади. Більшість дослідників відзначає, що ухилення від сплати податків, зборів (обов'язкових платежів) $\epsilon$ одним із найактуальніших питань у контексті запобігання появі податкових правопорушень та використанню резервів зростання фінансових ресурсів держави. До науковців, які займаються дослідженням проблеми ухилення від сплати податків, належать такі українські вчені: В. Вересов, А. Веткін, В. Вишневський, О. Дудоров, О. Задорожний, А. Крисоватий, І. Мельник, В.Молодик, Л. Омелянович, В. Останін,С. Онисько, Ю. Сухов та ін. [1; 5; 8; 11-13]. Проблеми податкової злочинності, особливості їі детермінації та запобігання стали предметом дослідження багатьох учених-кримінологів, зокрема В.В. Голіни, Д.І. Голосніченка, А.Є. Гутника, А.П. Зрєлова, І.М. Даньшина, О.Г. Кальмана, І.І. Кучерова, В.В. Пивоварова, В.М. Поповича та ін. [2-4; 7; 14].

Метою статті $\epsilon$ дослідження доктринальних положень щодо встановлення соціально-правової зумовленості кримінальної відповідальності за ухилення від сплати податків, зборів (обов'язкових платежів) через вивчення окремих статистичних даних та на їх підставі з'ясування такого принципу (критерію) криміналізації діяння, як достатня ступінь поширеності.

Виклад основного матеріалу. Ухилення від сплати податків, зборів (обов'язкових платежів) історично виникло і розвивалося паралельно з появою самих податків та зі становленням податкових систем різних країн. Ухилення від сплати податків притаманне будь-якому суспільству. Причиною цього $€$ очевидний вплив податків на доходи і витрати платників за недостатнього розуміння ними користі від отримання суспільних благ, які фінансуються за рахунок податкових платежів. Еволюція податкових відносин постійно свідчить про ухилення від оподаткування, що зумовлено як суб'єктивними, так і об'єктивними причинами. Оскільки саме через податки зменшується частина доходу, що залишається у розпорядженні суб'єкта господарювання, із цього й випливає його прагнення зменшити частину вилученого доходу, що можна зробити шляхом мінімізації або несплати податкових платежів. Саме законодавство через велике податкове навантаження (близько 60\%) може об'єктивно змушувати підприємців шукати недоліки у податкових законах або використовувати різні схеми фіктивних підприємств для ухилення від сплати податків. Усе це негативно відображається на продуктивному підприємництві.

Проблема масового ухилення від сплати податків в Україні пов'язана, перш за все, з тим, що податкова система країни тільки формується у складний період переходу до ринкової економіки, окрім цього, супроводжується кризовими явищами. Саме із цієї причини сьогодні вона недостатньо розвинута, містить велику кількість невідповідностей, до того ж дуже динамічно змінюється, що зумовлює появу великої кількості «лазівок» у законодавчих актах [19, с. 52-56]. Ухилення від сплати податків становить значну частину тіньової економіки країни. Міжнародна організація боротьби з відмиванням коштів оцінює реальні обсяги тіньової економіки у високорозвинутих країнах на рівні $17 \%$ ВВП, у країнах, що розвиваються, - 40\% ВВП, у країнах із перехідною економікою - понад 20\% ВВП [16, с. 20-23]. В Україні цей показник становить 44,1\%. Це свідчить про те, що до державного бюджету надходить менше коштів, аніж потрібно для виконання державою своїх функцій. Рівень тіньового сектору сьогодні все ще залишається високим, у ньому застосовуються більш витончені форми та схеми проведення тіньових операцій. Процес зниження рівня тінізації гальмується політичною нестабільністю й відсутністю судової, податкової та пенсійної реформ. Тіньова економіка $\epsilon$ дуже складним суспільним явищем, яке поділяється на велику кількість сегментів і механізмів отримання тіньових доходів. Це обов'язково треба брати до уваги, 
розробляючи державну програму протидії цьому явищу [15, с. 48-52]. Ухилення від сплати податків може реалізовуватися двома шляхами: шляхом використання незаконних методів і шляхом легалізованих дій. Ухилення від сплати податків в Українській економічній енциклопедії визначається як сукупність легальних і незаконних способів приховування доходів від оподаткування. Ухилення від сплати податків багато українських учених розмежовують на два методи: легалізоване зменшення оподаткування називають уникненням від сплати податків, а нелегальне - ухиленням від сплати податків. Ухилення від сплати податків - це протиправні дії суб'єктів господарювання, спрямовані на мінімізацію податкових зобов'язань усіма допустимими законодавством способами, наслідками яких у разі їх виявлення може бути відповідальність за порушення податкового законодавства. Значне поширення податкових правопорушень виникає під впливом різних обставин. Деякі з них діють на загальнодержавному рівні та відображають недоліки, пов'язані з кризовим станом економіки, інші зумовлені специфічними особливостями функціонування податкової служби в умовах протидії з боку правопорушників [15, с. 48-52]. Слід звернути увагу, що фізичні й юридичні особи намагаються будьякими способами зменшити суми податку, які потрібно сплатити, адже приховані від оподаткування кошти можна обміняти на певні індивідуальні блага або спрямувати на розвиток бізнесу та виробництва, на виплату заробітної плати або інвестиції. Саме така позиція платників податків зумовлює їх бажання не сплачувати податки. Передусім на існування в Україні проблеми ухилення від оподаткування впливає свідомість наших громадян, більшість з яких не вважає це серйозним кримінальним правопорушенням. На жаль, серед населення поширена думка, що людина, яка ухиляється від сплати податків, не $\epsilon$ злочинцем, а, навпаки, $\epsilon$ талановитим підприємцем та проявляє позитивні бізнесові здібності. Також слід зазначити, що бажання збагатитися не $\epsilon \in$ диною причиною ухилення від сплати податків.

Певним аспектам щодо визначення умов криміналізації на різних етапах приділяли увагу такі видатні науковці, як В.І. Курляндський, Г.А. Злобін, П.С. Дагель, О.І. Коробеєв, М.І. Хавронюк та ін. Аналізуючи питання щодо доцільності та обґрунтованості криміналізації ухилення від сплати податків, зборів (обов'язкових платежів), уважаємо за необхідне сформулювати та охарактеризувати такі соціально-правові підстави (кри- терії) криміналізації зазначеного протиправного діяння:

а) діяння, яке криміналізується, повинно бути суспільно небезпечним;

б) воно повинно мати достатню ступінь поширеності;

в) очікувані позитивні наслідки криміналізації повинні перевищувати іï негативні наслідки;

г) криміналізація не повинна суперечити Конституції України, чинному праву і міжнародним угодам України;

ґ) вона не повинна суперечити нормам моральності;

д) криміналізація повинна бути здійсненна в процесуальному і криміналістичному аспектах (тобто заборонене діяння буде можливо розкрити і розслідувати законними правовими засобами);

е) криміналізація не повинна проводитися, якщо боротьба з даними шкідливим для суспільства діяннями можлива й ефективна за допомогою інших, більш м'яких заходів [10, с. 22].

Спробуємо оцінити соціально-правову зумовленість кримінально-правової заборони, встановленої у ст. 212 КК України, з позиції розгляду одного з перерахованих вище критеріїв криміналізації діянь, а саме того, що воно повинно мати достатню ступінь поширеності. Підтвердженням важливості розгляду та з'ясування саме цього критерію $€$ думка у кримінально-правовій літературі про те, що у визначенні умов криміналізації будь-якого суспільно небезпечного діяння окреме значення має його достатня ступінь поширеності [9, с. 149].

Для оцінки рівня поширеності ухилення від сплати податків, зборів (обов'язкових платежів) було проаналізовано статистичні дані за 2013-2019 рр., які було синтезовано та опубліковано Офісом Генерального прокурора на офіційному вебсайті [17], а також статистичні дані Державної судової адміністрації України, вищих спеціалізованих судів, Верховного Суду України [18]. Для дослідження статистики щодо показників злочинності в Україні було вибрано такі часові рамки у зв'язку з набранням чинності 20 листопада 2012 р. КПКУ, яким було змінено процесуальну форму та процедури здійснення досудового розслідування у кримінальних провадженнях, а також ї розгляду в судах. Дані зміни вплинули на порядок ведення і статистичних даних, показники яких стали відрізнятися від показників минулих років.

Основні показники злочинності щодо ухилення від сплати податків, зборів (обов'язкових платежів) та результатів протидії даному явищу 
проілюстровано у таблиці статистичної інформації (табл. 1). Аналізом статистичної інформації за період 2013-2020 рр. було встановлено, що найбільш загальний показник облікованих кримінальних правопорушень у кримінальних проваджень на території України був у 2013 р. (всього 3375 кримінальних правопорушень), найменший - у 2020 р. При цьому можемо спостерігати, що починаючи з 2014 р. відбувається поступовий спад виявлення та реєстрації проваджень у такому процентному відношенні відносно показників 2014 р.: у 2015 р. - на 3\%, у 2016 р. - на 10\%, у 2017 р. - на 14\%, у 2018 р. - на $12 \%$, у 2019 р. - на $16 \%$, у 2020 р. - на 15\%.

Реальними показниками протидії кримінальним правопорушенням, котрі передбачені ст. 212 КК України на звітній період, які характеризують кількість кримінальних правопорушень, щодо яких було встановлено підозрювану особу, є відомості щодо кількості письмових повідомлень про підозру, направлення обвинувальних актів та клопотань про звільнення від кримінальної відповідальності до суду, результатів їх розгляду у судах кількість винесених вироків щодо обвинувачених осіб. Так, у 2013 р. було обліковано 3375 кримінальних правопорушень, передбачених ст. 212 КК України, з яких щодо 412 правопорушень особам було повідомлено про підозру, 141 обвинувальний акт направлено до суду, а 257 осіб було звільнено від кримінальної відповідальності; у 2014 р. було обліковано 2003 кримінальних правопорушення, передбачених ст. 212 КК України, з яких щодо 184 правопорушень особам було повідомлено про підозру, 41 обвинувальний акт направлено до суду, а 130 осіб було звільнено від кримінальної відповідальності; у 2015 р. було обліковано
1758 кримінальних правопорушень, передбачених ст. 212 КК України, з яких щодо 124 правопорушень особам було повідомлено про підозру, 43 обвинувальних акта було направлено до суду, а 67 осіб було звільнено від кримінальної відповідальності; у 2016 р. було обліковано 1172 кримінальних правопорушення, передбачених ст. 212 КК України, з яких щодо 115 правопорушень особам було повідомлено про підозру, 24 обвинувальних акта було направлено до суду, а 81 особа була звільнена від кримінальної відповідальності; у 2017 р. було обліковано 871 кримінальне правопорушення, передбачених ст. 212 КК України, з яких щодо 106 правопорушень особам було повідомлено про підозру, 27 обвинувальних актів було направлено до суду, а 61 особа була звільнена від кримінальної відповідальності; у 2018 р. було обліковано 983 кримінальних правопорушення, передбачених ст. 212 КК України, з яких щодо 119 правопорушень особам було повідомлено про підозру, 36 обвинувальних актів було направлено до суду, а 66 осіб було звільнено від кримінальної відповідальності; у 2019 р. було обліковано 693 кримінальних правопорушення, передбачених ст. 212 КК України, з яких щодо 88 правопорушень особам було повідомлено про підозру, 20 обвинувальних актів було направлено до суду, а 66 осіб було звільнено від кримінальної відповідальності; у 2020 р. було обліковано 771 кримінальне правопорушення, передбачених ст. 212 КК України, з яких щодо 41 правопорушення особам було повідомлено про підозру, 10 обвинувальних актів було направлено до суду, а 27 осіб було звільнено від кримінальної відповідальності.

Отже, що стосується показників кримінальних правопорушень, за якими провадження направлені

Таблиця 1

Дані статистичної інформації

\begin{tabular}{|c|c|c|c|c|c|c|c|c|c|}
\hline \multirow{2}{*}{\multicolumn{2}{|c|}{$\begin{array}{c}\text { Відомості щодо кримінальних право- } \\
\text { порушень }\end{array}$}} & \multicolumn{8}{|c|}{ Обліковий період (роки) } \\
\hline & & 2013 & 2014 & 2015 & 2016 & 2017 & 2018 & 2019 & 2020 \\
\hline \multicolumn{2}{|r|}{$\begin{array}{c}\text { Всього обліковано } \\
\text { кримінальних правопорушень }\end{array}$} & 3375 & 2003 & 1758 & 1172 & 871 & 983 & 693 & 771 \\
\hline \multirow{6}{*}{ 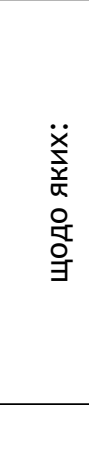 } & $\begin{array}{l}\text { кримінальне провадження } \\
\text { закрито }\end{array}$ & 2908 & 972 & 792 & 316 & 161 & 163 & 206 & 1 \\
\hline & особі повідомлено про підозру & 412 & 184 & 124 & 115 & 106 & 119 & 88 & 1 \\
\hline & $\begin{array}{l}\text { направлені до суду - обвину- } \\
\text { вальний акт }\end{array}$ & 141 & 44 & 43 & 24 & 27 & 36 & 0 & 0 \\
\hline & $\begin{array}{l}\text { направлені до суду - з кло- } \\
\text { потанням про звільнення від } \\
\text { кримінальної відповідальності }\end{array}$ & 257 & 130 & 67 & 81 & 61 & 66 & 6 & 7 \\
\hline & $\begin{array}{l}\text { особами, які раніше вчиняли } \\
\text { кримінальні правопорушення }\end{array}$ & 6 & & 2 & & 4 & 2 & 3 & \\
\hline & Групою осіб & 5 & 5 & 6 & 4 & 3 & 7 & 1 & 2 \\
\hline
\end{tabular}


до суду щодо встановлення обвинувального акту, то вони зменшилися у відсотковому значенні так: у 2013 р. - 41\%, у 2014 р. - 12\%, у 2015 р. - 13\%, у 2016 р. - 7\%, у 2017 р. - 8\%, у 2018 р. - 10\%, у 2019 р. - 6\%, у 2020 р. - 3\%. Щодо показників, які стосуються кримінальних правопорушень, за якими провадження направлені до суду з клопотанням про звільнення від кримінальної відповідальності, також спостерігається зменшення, a саме: у 2013 р. - 34\%, у 2014 р. - 17\%, у 2015 р. 9\%, y 2016 p. - 11\%, y 2017 p. - 8\%, y 2018 p. - 9\%, у 2019 р. - $9 \%$, у 2020 р. - 3\%.

Слід зауважити, що однією з причин зменшення показників притягнення до кримінальної відповідальності за відповідною статтею, на нашу думку, $\epsilon$ альтернатива, передбачена ч. 5 ст. 212 КК України.

Висновки. Підсумовуючи зазначене, маємо дійти висновку, що встановлення кримінальної відповідальності за ухилення від сплати податків, зборів (обов'язкових платежів) загальновизначений науковий критерій криміналізації діянь (достатня ступінь поширеності) підтверджується даними Офісу Генерального прокуратура України та вказує на соціально-правову зумовленість ст. 212 КК України. Проаналізувавши вказані дані стосовно справ про кримінальні правопорушення щодо осіб, які притягнуті до кримінальної відповідальності, можна впевнено констатувати, що ухилення від сплати податків, зборів (обов'язкових платежів), на жаль, $\epsilon$ достатньо розповсюдженим явищем. Отже, єдність критеріїв поширеності ухилення від сплати податків, зборів (обов'язкових платежів) та ступеня суспільної небезпеки зазначеного протиправного діяння у своїй сукупності $\epsilon$ підставою для ствердження, що ухилення від сплати податків, зборів (обов'язкових платежів) має певні проблеми щодо попередження кримінального правопорушення, передбаченого ст. 212 КК України, та потребує пошуків нових засобів протидії. Окрім того, навіть без урахування великого латентного масиву кримінальних правопорушень за ухилення від сплати податків, зборів (обов'язкових платежів) можна впевнено стверджувати про їх масовість та поширеність як підстави встановлення кримінально-правової заборони. Такі важливі методи кримінально-правової політики, як криміналізація та декриміналізація щодо кримінального правопорушення, передбаченого ст. 212 КК України, мають реалізовуватися 3 використанням дослідженого критерію криміналізації з урахуванням прак- тики застосування норм кримінального закону, а також відповідно до потреб держави та стану суспільних відносин.

\section{Література}

1. Вишневский В.П., Веткин А.П., Вишневская Е.Н. Налогообложение: теории, проблемы, решения / под общ. ред. В.П. Вишневского. Донецк : ДонНтУ, 2006. 504 c.

2. Голіна В.В. Кримінологічні та кримінальноправові проблеми боротьби з бандитизмом: соціально-правове та кримінологічне дослідження. Харків : Регіонынформ, 2004. 212 с.

3. Гутник А.Є. Запобігання податковою міліцією ухилення від сплати податків. Київ : Атіка, 2001. 176 c.

4. Даньшин Н.И. Общетеоретические проблемы криминологии. Харьков : Прапор, 2005. 224 с.

5. Дудоров О. Кримінально-правовий досвід Нової Зеландії у питанні протидії податковій злочинності. Підприємство, господарство і право. 2008. № 5. С. 87-90.

6. Єдиний державний реєстр судових рішень. URL: https://reyestr.court.gov.ua/.

7. Кальман О.Г. Стан і головні напрямки попередження економічної злочинності: теоретичні та прикладні проблеми. Харків : Гімназія, 2003. 352 с.

8. Крисоватий А.І., Кізима А.Я. Податковий менеджмент : навчальний посібник. Тернопіль : Карт-бланш, 2004. 304 с.

9. Основания уголовно-правового запрета: Криминализация и декриминализация / В.Н. Кудрявцев и др. ; отв. ред. В.Н. Кудрявцев, А.М. Яковлев. Москва, 1982. 304 с.

10. Курс российского уголовного права: Общая часть / под ред. В.Н. Кудрявцева, А.В. Наумова. Москва, 2001. 767 с.

11. Мельник В.М. Обмежувальна та стимульована роль податків. Фінанси України. 2006. № 1. С. 24- 28.

12. Омельянович О.Л., Орлова В.О. Податкова система : навчальний посібник. Донецьк : ДонДУЕТ, 2008. 276 с.

13. Онисько С.М. Податкова система : підручник. Львів : Магнолія, 2008. 336 с.

14. Пивоваров В.В. Податкова і кредитно-фінансова злочинність: кримінологічна характеристика та попередження : дис. ... канд. юрид. наук : 12.00.08. Харків, 2003. 227 с.

15. Сидоренко Т.О. Сутність та причини ухилення від сплати податків. Економічний часопис ХХІ. 2010. № 5-6. С. 48-52.

16. Собуцький С. Місце під «тінню». Вісник податкової служби України. 2008. № 37. С. 20-23. 
17. Статистичні дані Офісу Генерального прокypopa/ URL: https://www.gp.gov.ua/ua/1stat.

18. Статистичні дані. Судова влада України. URL: https://supreme.court.gov.ua/supreme/ gromadyanam/kontakts/].

19. Тищенко О.М., Єніна-Березовська А.О. Ухилення від сплати податків та причини його виникнення. Вісник Університету банківської справи НБУ. 2009. № 1(4). С. 52-56.

20. Филимонов В.Д. Криминологические основы уголовного права. Томск, 1981. 213 c.
Гритенко О. А., доктор юридичних наук, доцент, професор кафедри кримінального права та кримінології

одеського державного університету внутрішніх справ

Старинець $\epsilon$. А., аспірант кафедри кримінального права та кримінології

Одеського державного університету внутрішніх справ 